\title{
The Effect of Giving Purple Sweet Potato Leaves Toward The Involution of Mother in The Posture and Sufficient Mother Breast Milk On Babies 0-6 Months
}

\author{
Nur Zad Malikha, Retno Dewi Prisusanti* \\ Akademi Kebidanan Wijaya Kusuma Malang, East Java Indonesia \\ Corresponding author: ikkamalikha@yahoo.com
}

\begin{abstract}
Background: One of the exclusive breastfeeding failures is because of low milk production, while uterine involution is also a complication that often occurs in the puerperium that can contribute to maternal mortality, nonpharmacological therapy that can be given, among others, the provision of purple sweet potato leaves.

Purpose: This study aimed to determine the effect of giving purple sweet potato leaves to uterine involution in puerperal mothers and the adequacy of breast milk.

Method: This type of research is a quosy experimental only with a sample of 35, sampling with the Purposive Sampling technique. The provision of purple sweet potato leaves is given for 7 days, namely the 8-14 day of the puerperium, and measurement of uterine involution indicators and the adequacy of breast milk is done before and after administration of purple sweet potato leaves. Analysis using the Wilcoxon test.

Results: The results of the study are the effect of giving purple sweet potato leaves to uterine involution in postpartum mothers and the adequacy of breast milk in infants $0-6$ months (p-value $=0,000$ ).

Conclusion: There is an effect of giving purple sweet potato leaves to uterine involution in puerperal mothers and the adequacy of breast milk in infants aged 0-6 months.
\end{abstract}

Keywords: Purple sweet potato leaves, Uterine involution, Breast milk adequacy 


\section{BACKGROUND}

The recommendation for exclusive breastfeeding during the first 6 months is based on several studies on the benefits of breastfeeding for the baby's immune system, growth, and development. Indonesia has set a national target in 2014 of $80 \%$ as the exclusive ASI coverage figure $(\mathrm{MOH}, 2014)$

Involution or contraction of the uterus is a process in which the uterus returns to prepregnancy conditions weighing about 60 grams. This process begins immediately after the placenta is born due to the contraction of the smooth muscles of the uterus (Anggraeni, 2010). Postpartum mothers need nutritional quality foods that are high in protein, vegetables, and fruits that contain lots of vitamins that support the healing process (Mochtar, 2011). Purple sweet potato leaves (Ipomoea batatas var Ayamurasaki) contain high Fe, Provitamin A, and protein, carotenoids, and iron as well as oxytocin/prolactin which can support the success of breast milk and accelerate the process of uterine involution (Truong, 2010).

From the description above, the researcher wants to research the effect of giving purple sweet potato leaves to uterine involution in postpartum mothers and the adequacy of ASI (breast milk) in infants 0-6 months. To determine the effect of giving purple sweet potato leaves to uterine involution in postpartum mothers and the adequacy of ASI (breast milk) in infants 0-6 months. Exclusive breastfeeding can reduce infant mortality due to various diseases such as diarrhea and inflammation of the lungs, and accelerate recovery when sick and spacing pregnancy. And the occurrence of uterine sub involution can increase the maternal mortality rate in the puerperium.

\section{OBJECTIVES}

This study aimed to determine the effect of giving purple sweet potato leaves to uterine involution in puerperal mothers and the adequacy of breast milk

\section{METHODS}

This type of research is experimental research, with a quantitative approach. The study design uses a quasy experiment. The population in this study was the post-partum mother's day 8-14 in May - July at 8 Tlogowaru village Integrated Healthcare Centre. The sampling technique was a purposive sampling of 35 postpartum mothers. Criteria included in this study are:

1) Mother childbirth more than 7 days

2) Mother childbirth involution is not normal

3) Postpartum mothers who do not experience ASI dams

4) Postpartum mothers whose milk is not smooth

5) Postpartum mothers who are willing to become research respondents

6) Babies are born at term

7) Babies older than 7 days

8) A healthy baby

9) Babies without congenital abnormalities such as labioskisis and labio palatoskisis

Bivariate analysis using the Wilcoxon test.

The participants were assured that their engagement was voluntary, and that anonymity, privacy, and confidentiality of the data were guaranteed. Furthermore, they were informed about the purpose and the method of the study before signing a written informed consent. 
The questionnaires were distributed to eligible participants at the Tlogowaru village Integrated Healthcare Centre, and respondents were asked to complete and return them in the same time.

\section{RESULT}

1. General Data

a. Age of Respondents

\begin{tabular}{llcc}
\hline No & Old & Frequency $(\mathrm{n})$ & Percentage $(\%)$ \\
\hline 1 & $20-25$ year & 2 & 5,7 \\
2 & 26-30 year & 21 & 60,0 \\
3 & 31-35 year & 11 & 31,4 \\
& Total & 35 & 100 \\
\hline
\end{tabular}

b. Education of Respondent

\begin{tabular}{lccc}
\hline No & Level of education & Frequency $(\mathrm{n})$ & Percentage (\%) \\
\hline 1 & Junior high school & 2 & 5,7 \\
2 & Senior high school & 29 & 82,9 \\
3 & Collage & 4 & 11,4 \\
& Total & 35 & 100 \\
\hline
\end{tabular}

c.Respondents job

\begin{tabular}{llcc}
\hline No & Job & Frequency $(\mathrm{n})$ & Percentage $(\%)$ \\
\hline 1 & Work & 24 & 68,6 \\
2 & \multicolumn{1}{c}{ Does not work } & & 31,4 \\
& Total & 35 & 100 \\
\hline
\end{tabular}

d. Parity of Respondents

\begin{tabular}{llcc}
\hline No & Parity & Frequency (n) & $\begin{array}{c}\text { Percentage } \\
(\%)\end{array}$ \\
\hline 1 & Parity 1 & 14 & 40,0 \\
2 & Parity 2 & 17 & 48,6 \\
3 & Parity 3 or more & 4 & 11,4 \\
& Total & 35 & 100 \\
\hline
\end{tabular}

2. Special Data

a. Uteric Involution

\begin{tabular}{|c|c|c|c|c|c|}
\hline \multirow[t]{2}{*}{ No } & \multirow{2}{*}{$\begin{array}{l}\text { Uteric } \\
\text { Involution }\end{array}$} & \multicolumn{2}{|c|}{ Before Treatment } & \multicolumn{2}{|c|}{ After Treatment } \\
\hline & & Frequency (n) & Percentage $(\%)$ & Frequency (n & Percentage $(\%)$ \\
\hline 1 & Normal & & & 19 & 54,3 \\
\hline \multirow[t]{2}{*}{2} & Not normal & 35 & 100 & 16 & 45,7 \\
\hline & Total & 35 & 100 & 35 & 100 \\
\hline
\end{tabular}




\begin{tabular}{|c|c|c|c|c|c|}
\hline \multirow[t]{2}{*}{ No } & \multirow[t]{2}{*}{ Adequacy ASI } & \multicolumn{2}{|c|}{ Before treatment } & \multicolumn{2}{|c|}{ After treatment } \\
\hline & & Frequency (n) & Percentage (\%) & Frequency (n) & Percentage $(\%)$ \\
\hline 1 & Enough & & & 26 & 74,3 \\
\hline 2 & Less & 27 & 77,1 & 9 & 25,7 \\
\hline 3 & Very Less & 8 & 22,9 & & \\
\hline & Total & 35 & 100 & 35 & 100 \\
\hline
\end{tabular}

c. Data Analysis

\begin{tabular}{lrrr}
\hline Test Statistics & \multicolumn{2}{c}{ Day 15th Involution- Day 17th } & ASI 15th day- ASI 7th day \\
Involution & $-4,359^{\mathrm{b}}$ & $-5,353^{\mathrm{c}}$ \\
Z & 000 &, 000 \\
Asymp. Sig. (2-tailed) &, 000 &, \\
\hline
\end{tabular}

Analysis of the Effect of giving purple sweet potato leaves to uterine involution in puerperal mothers and the adequacy of breast milk in infants $0-6$ months in Tlogowaru village integrated healthcare center with a significance value of $0,000<0.05$ can be concluded that $\mathrm{H} 1$ is accepted and $\mathrm{H} 0$ is rejected.

\section{DISCUSSION}

The results of the research analysis showed a change in which before being given treatment all respondents $(100 \%)$ had abnormal uterine involution so that after treatment as many as $54.3 \%$ of respondents had normal uterine involution. Whereas for the adequacy of ASI before being treated as much as $77.1 \%$ the ASI was lacking and after being treated as much as $74.3 \%$ of respondents ASI was sufficient. The results obtained $\mathrm{H} 1$ accepted so that there is an effect of giving purple sweet potato leaves to uterine involution in puerperal mothers and the adequacy of breast milk in infants 0-6 months.

This result is following Abdul Bari's theory. S, et al, (2002) which says that the presence of oxytocin effect causes uterine contractions. The oxytocin hormone that has been released from the pituitary gland strengthens and regulates uterine contractions, compresses blood vessels and helps the hemostatic process. The uterine muscle contractions and retractions reduce the blood supply to the uterus. This process helps reduce bleeding. Breastfeeding immediately after the baby is born will stimulate the release of oxytocin due to the baby sucking on the breast. This theory is supported by Prof. Dr. Ahmad Sulaeman, food expert from IPB that "Sweet potato leaves can improve infant nutrition, because these leaves can increase milk production," Prof. Ahmad explained that there were efforts to increase milk production through consumption sweet potato leaves, this is because in these leaves there are lactagogum substances that can increase milk production, in addition to this leaf there are also caroteniid and iron contents.

Ritawati L, (2012), in her research on the Success of Exclusive Breastfeeding with sweet potato leaves in postpartum mothers that sweet potato leaves contain oxytocin/prolactin which can increase milk production. Increased milk production will encourage mothers to breastfeed more frequently and with breastfeeding more often there 


\section{Journal Of Nursing Practice}

http://thejnp.org

ISSN: 2614-3488 (print); 2614-3496 (online)

Vol.3 No.1. October 2019. Page.96-101

will be positive feedback on the increase in the hormone oxytocin which is very helpful for uterine contractions, compressing blood vessels and helping the hemostatic process. This process will help reduce bleeding so that lochea in the puerperal mother will be reduced and decrease the Uterine Fundus Height. Thus the Research Hypothesis can be proven that consumption of sweet potato leaves can accelerate the involutional process in puerperal mothers, ie accelerate the decrease in TFU and accelerate the decay of puerperal blood/lochea.

Sweet potato leaves are believed to be very effective as herbal medicines. That is because sweet potato leaves contain various kinds of substances that the body needs such as vitamin A, vitamin B, vitamin B6 vitamin C. Sweet potato leaves also contain almost $7 \%$ protein, $15 \%$ crude fiber. This leaf is rich in vitamin $\mathrm{A}$, in addition to provitamin $\mathrm{A}$ (beta carotene), $\mathrm{B}$ and $\mathrm{C}$, iron, calcium, phosphorus and fat (Raifa, 2008).

The supply of ASI is a very matter to play a role in the lactation/breastfeeding process. The more adequate milk supply for babies the more successful the process of breastfeeding is done and vice versa. Adequacy of baby's milk obtained by consuming sweet potato leaves decoction regularly ie every $2 \mathrm{x} /$ day for 7 days, with a dose of 100 grams of sweet potato leaves every day during the process of breastfeeding will get maximum results, with that the adequacy of breast milk will meet the nutrients needed by the baby will be fulfilled properly.

\section{CONCLUSION}

Uterine infusion in postpartum mothers before treatment in the abnormal category (35 respondents), after consuming purple sweet potato leaves as many as $54.3 \%$ of respondents in the normal uterine involution category. Likewise, from the indicator of ASI adequacy from the beginning in the category of insufficient and very insufficient, after receiving adequate treatment the milk is sufficient and insufficient.

There is an effect of giving purple sweet potato leaves to uterine involution in puerperal mothers and the adequacy of breast milk in infants aged 0-6 months in the Tlogowaru village integrated healthcare center $(\mathrm{p}$-value $=0,000)$.

\section{SUGGESTION}

It is hoped that with this research, respondents who are postpartum and breastfeeding mothers can understand the importance of nutrition to restore the function of reproductive organs and support the supply of breast milk by making purple sweet potato leaves present in a variety of foods or drinks.

It is hoped that with this research, the land that is the location of the study will be more open to all information related to the efforts that can be made by the relevant sectors and work together with the local health office in an effort to develop awareness and the ability of the community to provide support to postpartum mothers to pay attention to their health and for mothers breastfeed to keep giving milk to babies to improve the degree of health of mother and baby.

\section{REFERENCES}

Depkes RI. 2014. Petunjuk Pelaksanaan Peningkatan ASI Ekslusif. Jakarta : Depkes RI

Anggraini. 2010. Asuhan Kebidanan Masa Nifas. Yogyakarta: CV Pustaka Rihama

Mochtar Rustam. 2011. Sinopsis Obstetri Fisiologi dan Obstetri Patofisiologi Edisi 3 Jilid I. 
Jakarta: EGC.

Truong. 2010. Kajian aspek pembibitan, budidaya, dan pemanfaatan umbi-umbian sebagai sumber pangan alternative, Laporan Hasil Penelitian. Kerjasama BAPEDA Propinsi Bali dengan Fakultas Pertanian Universitas Udayana.

Raifa. 2008. Daun Ubi Jalar Sehatkan Ibu Dan Bayi. Majalah Kartini. Nomor:2134, hal. 148

Rahayu M. dkk, 2006 Pemanfaatan Tumbuhan Obat Secara Tradisional oleh masyarakat Lokal di Pulau Wawonii, Sulawesi Tenggara. Jurnal Bioversitas Volume 7 Nomor 3 (Hal 245-250) ISSN: 1412-033X

Ritawati L 2012, Jurnal Penelitian Sukses ASI Eksklusif dengan daun ubi jalar pada Ibu Nifas.

Sujiyatini, dkk 2010. Catatan Kuliah Asuhan Ibu Nifas Askeb III. Yogyakarta : Cyrillus 


\section{Journal Of Nursing Practice}

